\title{
Comparison of the Ground Vegetation in Spruce Plantations and Natural Forest in the Greater Fundy Ecosystem, New Brunswick
}

\author{
Cam Veinotte, Bill Freedman ${ }^{1}$, Wolfgang Maass, and Friederike Kirstein
}

Department of Biology, Dalhousie University, Halifax, Nova Scotia B3H 4J1 Canada

${ }^{1}$ Corresponding author

Veinotte, Cam, Bill Freedman, Wolfgang Maass, and Friederike Kirstein. 2003. Comparison of the ground vegetation in spruce plantations and natural forest in the Greater Fundy ecosystem, New Brunswick. Canadian Field-Naturalist 117(4): 531-540.

We studied changes in ground vegetation associated with the conversion of natural, mature, mixed-species forest into conifer plantations in southeastern New Brunswick. This was done to determine the degree to which plant-associated biodiversity was affected by this forestry practice. Species of lichens, bryophytes, and vascular plants were examined in a 21-year chronosequence of 12 Black Spruce (Picea mariana) plantations and compared to 8 stands of natural forest of the type replaced. The richness, diversity, and density of species were greatest during younger stages of the plantation sere, with as many as 170 species occurring in a 6-year-old stand. Species occurred in successional stages according to their abilities to: (a) survive disturbances associated with clear-cutting and plantation establishment; (b) regenerate vegetatively; (c) re-establish from a persistent seedbank; (d) invade disturbed habitat by dispersed seeds; and/or (e) tolerate environmental stress imposed by the overtopping canopy during stand development. Multivariate analyses suggested that successional factors had the strongest influence on differences in the ground vegetation among stands of various ages. Gaps in the canopy of reference forest and older plantations provided microsite conditions similar to those of early seral stages, allowing some ruderal species to persist in older stands. Nonindigenous species were almost entirely limited to younger plantations. Some species of natural forest were rare or absent from plantations and may be at risk from the extensive development of these agroforestry habitats in our study region; these included Acer pensylvanicum, Cephaloziella spp., Chiloscyphus spp., Fagus grandifolia, Lepidozia reptans, Nowellia curvifolia, Odontoschisma denudatum, and Viburnum alnifolium

Key Words: forestry, plantations, clear-cutting, plant communities, ground vegetation, environmental impact, New Brunswick.

Of all methods of timber harvesting, clear-cutting causes the greatest change in forest ecosystems. Important effects include: reduction of biomass and nutrient capital (with potential damage to site quality and decreased carbon storage), increased erosion, altered hydrology, and changes in biodiversity at the levels of species, community, and landscape (Anonymous 1986; Freedman et al. 1994; Freedman 1995; Kohm and Franklin 1997; Mallik et al. 1997; Hunter 1999; Lindenmayer and Franklin 2002; Kimmins 2003). The changes in composition and diversity of plant communities after clear-cutting and associated management practices, such as those involving plantation establishment, are influenced by biotic and abiotic qualities of the site and by the colonizing and competitive abilities of particular species (Grime 1979; Smith 1980; Crowell and Freedman 1994; Freedman 1995).

Our study area in southeastern New Brunswick is in a region of the Maritime Provinces and eastern Maine where the natural Acadian (or Northern Appalachian) Forest has been reduced greatly in extent. The reduction is a result of clear-cut logging and plantation establishment, along with wildfire and the development of agricultural, residential, and tourism-related land uses. Our study area is part of the Greater Fundy Ecosystem (GFE), consisting of Fundy National Park a protected area of $206 \mathrm{~km}^{2}$ plus its nearby surrounding area, which is largely a mosaic of plantations, recent clear-cuts, some agricultural land, and residual stands of natural forest. Within this landscape-scale context, there is a need to conserve indigenous biodiversity, even while extensive tracts are being utilized to support economically important activities, including commercial forestry, agriculture, and tourism. At this scale, it is important to have large protected areas, such as the national park, but also to practise conservation-minded management in tracts that form the dominant "matrix" between protected areas, such as lands used for forestry. If this is to be done, then knowledge is required about the standand landscape-level risks to indigenous biodiversity that are associated with management practices, such as the conversion of natural forest into intensively managed forestry plantations.

Although Fundy National Park conserves a large area of natural forest, its ecological integrity is being challenged by anthropogenic stressors (Woodley et al. 1993, 1998; Freedman et al. 1994). There are stressors within the national park associated with extensive tourism-related development and a regionally important highway - these land-uses and related activities have caused habitat loss and stress to native species. For instance, more than 130 non-native plants now occur in the park (Burzynski et al. 1986); their abundance is partly due to agricultural practices occurring before park designation and to ongoing maintenance of grassy habitat around buildings, in campgrounds, and along roads. 
In addition, most terrain around and adjacent to the park is being intensively managed for industrial forestry - natural, mixed-species forest has been extensively clear-cut and converted to conifer plantations, greatly changing the ecological character of sites and landscape. In part, this management system has been implemented because of economic damage caused to natural forest by the most recent irruption of Spruce Budworm (Choristoneura fumiferana). Although natural forest regenerates well after budworm-caused damage, because of a vigorous advance regeneration of seedlings of fir and spruce, commercial forestry interests often prefer to replace damaged stands with plantations of higher productivity. Stands within the national park are not directly affected by these forestry practices. However, the extensive conversion of natural forest into plantations in the surrounding area may indirectly affect ecosystems and species within the park through habitat diminishment and insularization, changes in hydrology, and other influences.

In the present study, we examined differences in species composition, richness, and diversity in the ground vegetation of spruce plantations of various ages, and compared them with reference stands of natural forest of the type that have been converted into the plantations. The objectives of the study are to: (1) describe successional development of plantations and the growth strategies of key species of plants, bryophytes, and lichens; (2) to identify potential risks to indigenous species; and (3) to determine whether non-native plants are invading the managed habitats.

\section{Materials and Methods \\ Study Area}

Our study area (centered at $45^{\circ} 66^{\prime} \mathrm{N}$ and $65^{\circ} 10^{\prime} \mathrm{W}$ ) is in southeastern New Brunswick, Canada. It is located in the Atlantic Maritime Ecozone (Ecological Stratification Working Group 1995), within the Fundy Plateau Ecodistrict of the Southern Uplands Ecoregion of the Acadian Forest Region (Loucks 1962; Rowe 1972). The natural forest of the ecodistrict is dominated by mixed-species stands of Red Spruce (Picea rubens), White Spruce (P. glauca), Balsam Fir (Abies balsamea), Sugar Maple (Acer saccharum), Red Maple (A. rubrum), Yellow Birch (Betula alleghaniensis), White Birch (B. papyrifera), and Mountain Birch (B. cordifolia). Extensive disturbances, largely related to natural irruptions of Spruce Budworm, have resulted in most mature natural forest having a mixed-species canopy with patches of regenerating coniferous and angiosperm trees.

\section{Study Sites}

Twenty sites of at least 10 hectares were selected for study (Table 1). All sites occur in a relatively small area and are within $4 \mathrm{~km}$ of at least one other site. The sites were chosen to be comparable in topography, climate, elevation, site quality, and disturbance history, and to be accessible from the local road network. All sites are well-drained, on broadly flat terrain with no slopes greater than five degrees, and with loamy soil over a parent material of upland glacial till (Woodley, 1985). The soil association is a humo-ferric Lomond podzol (Canada Soil Survey Committee 1978; Maliondo et al. 1990).

Twelve of the study sites were Black Spruce (Picea mariana) plantations of various ages (3 to 21 years post-establishment; the latter was the oldest plantation in the area) located within $5 \mathrm{~km}$ of Fundy National Park. The plantations were all established by the same forestry company and originated with clear-cutting, site preparation by crushing, planting of spruce seedlings, and a release treatment with herbicide at 3-5 years of age. The other eight sites supported natural, mature, mixedwood forest. These "reference" stands were mostly within the park, but were nevertheless located close to the plantations studied (in several cases, on the opposite side of a boundary road). The reference stands were representative of the mixedspecies forest that had been harvested and converted into nearby plantations. Stand age was determined by coring eight dominant and subdominant trees per stand. Although the reference stands were mature at the time of our study, they may have been selectively logged prior to 60-70 years ago (the park was established in 1948) when there were several local sawmills (Burzynski 1985). The selective logging was followed by natural regeneration.

\section{Data Collection}

The ground vegetation was sampled in July and August in 1995 or 1996 . The sampling was done in 30 quadrats $(1 \mathrm{~m} \times 1 \mathrm{~m})$ located randomly along transects. The percent cover of species of vascular plants, bryophytes, and lichens was estimated visually as the proportion of ground surface obscured by a perpendicular projection of the foliage. Because foliage could be layered, total cover could exceed $100 \%$. If cover of a species was less than $1 \%$, it was noted as "present" and assigned a nominal value of $0.1 \%$. After the 30 quadrats were sampled a wider reconnaissance was made over the study site for 2030 minutes; any additional species found were assigned a value of $0.1 \%$ in the community analysis. Taxonomy of vascular plants follows Hinds (2000), while bryophytes follow Crum (1976) and lichens Brodo et al. (2001).

To provide data on habitat and stand structure, living and dead trees (i.e., with diameter at breast height $\geq 5.0 \mathrm{~cm}$ ) in reference stands were sampled for DBH in 12 plots of $20 \mathrm{~m} \times 20 \mathrm{~m}$ per stand. Because tree distribution and size were relatively homogenous in plantations, they were sampled in fewer (9) plots of a smaller size $(10 \mathrm{~m} \times 10 \mathrm{~m})$. Shrub-sized plants were identified and their diameter measured at $25 \mathrm{~cm}$ in two $5 \mathrm{~m} \times 5 \mathrm{~m}$ subquadrats nested in opposite corners of each tree quadrat (18-24 quadrats per stand). The field data were used to calculate density (stems/ha) 
TABLE 1 . General description of research stands. TBA is tree basal area $\left(\mathrm{m}^{2} / \mathrm{ha}\right)$; SBA is shrub basal area $\left(\mathrm{m}^{2} / \mathrm{ha}\right)$. The data for tree species are relative dominance.

\begin{tabular}{|c|c|c|}
\hline Site Name & Site Description & Dominant Trees \\
\hline $\mathrm{R} 1$ & $\begin{array}{l}\text { Mature conifer-dominated mixedwood, } 60-90 \text { yr old, some } \\
\text { budworm damage; TBA } 29.3 \text {, SBA } 1.8\end{array}$ & $\operatorname{Pr} 74 \%$; Bc $11 \% ; \operatorname{Ar} 10 \% ; \mathrm{Ba} 3 \% ; \mathrm{Bp} 1 \%$ \\
\hline $\mathrm{R} 2$ & $\begin{array}{l}\text { Mature mixedwood, } 80-130 \text { yr old, some budworm damage; } \\
\text { TBA 29.1, SBA } 1.9\end{array}$ & $\operatorname{Pr} 58 \% ;$ Ba $27 \% ;$ Ar $8 \% ;$ Bc $6 \%$ \\
\hline R3 & $\begin{array}{l}\text { Tolerant hardwood, } 60 \text { yr old, small-scale, selective logging } \\
\text { before 1947; TBA 33.1, SBA } 1.1\end{array}$ & As $26 \%$; Ba $21 \%$; Pr $17 \%$; Ar $17 \%$; Bc $12 \%$ \\
\hline $\mathrm{R} 4$ & $\begin{array}{l}\text { Mature conifer-dominated mixedwood, } 55-140 \text { yr old, } \\
\text { extensive budworm damage; TBA 28.0, SBA } 2.8\end{array}$ & $\operatorname{Pr} 68 \% ; \mathrm{Ba} 16 \% ;$ Ar $13 \% ;$ Bc $3 \%$ \\
\hline R5 & $\begin{array}{l}\text { Mature mixedwood, } 60 \text { yr old, some budworm damage; } \\
\text { TBA 25.4, SBA } 2.4\end{array}$ & As $40 \%$; Pr $27 \%$; Ar $12 \%$; Ba $12 \%$; Fg $10 \%$ \\
\hline R6 & $\begin{array}{l}\text { Mature mixedwood, } 55 \text { yr old, some budworm damage; } \\
\text { TBA } 27.7 \text {, SBA } 2.8\end{array}$ & As $34 \%$; Pr 27\%; Ar 18\%; Fg 16\%; Ba 4\% \\
\hline R7 & $\begin{array}{l}\text { Mature mixedwood, } 60-80 \text { yr old, some budworm damage; } \\
\text { TBA 30.5, SBA } 0.9\end{array}$ & As $50 \%$; Pr 32\%; Ba $12 \%$; Ar 6\% \\
\hline $\mathrm{R} 8$ & $\begin{array}{l}\text { Mature conifer-dominated mixedwood, } 75-110 \text { yr old, some } \\
\text { budworm damage; TBA } 28.7 \text {, SBA } 2.0\end{array}$ & $\operatorname{Pr} 78 \%$; Ba $12 \%$; Bc 5\%; Ar 3\%; As $2 \%$ \\
\hline $\mathrm{P} 21$ & $21 \mathrm{yr}$ old, clearcut, planted with spruce, TBA 15.1 , SBA 1.0 & $\mathrm{Pm} 71 \% ; \mathrm{Ab} 28 \% ; \mathrm{Pg} 1 \%$ \\
\hline P18 & $18 \mathrm{yr}$ old, as above; TBA 10.8 , SBA 6.2 & $\mathrm{Pm} 73 \% ; \mathrm{Ab} 27 \%$ \\
\hline $\mathrm{P} 15$ & $15 \mathrm{yr}$ old, as above; TBA 28.8, SBA 3.2 & $\mathrm{Pm} 78 \% ; \mathrm{Ab} 22 \%$ \\
\hline P13 & $13 \mathrm{yr}$ old, as above; TBA 5.6, SBA 0.7 & $\mathrm{Pm} 79 \% ; \mathrm{Ab} 21 \%$ \\
\hline P8 & 8 yr old, as above; TBA 5.1, SBA 3.7 & $\mathrm{Ab} 58 \% ; \mathrm{Pm} 42 \% ; \mathrm{Bc} 1 \%$ \\
\hline $\mathrm{P} 7$ & $7 \mathrm{yr}$ old, as above; TBA 0.5 , SBA 4.6 & No tree-sized plants \\
\hline P6a & $6 \mathrm{yr}$ old, as above; TBA 0.0 , SBA 2.0 & No tree-sized plants \\
\hline P6b & $6 \mathrm{yr}$ old, as above; TBA 0.3 , SBA 4.6 & No tree-sized plants \\
\hline P5a & $5 \mathrm{yr}$ old, as above; TBA 0.0 , SBA 1.5 & No tree-sized plants \\
\hline $\mathrm{P} 5 \mathrm{~b}$ & $5 \mathrm{yr}$ old, as above; TBA 0.0 , SBA 0.9 & No tree-sized plants \\
\hline $\mathrm{P} 4$ & $4 \mathrm{yr}$ old, as above; TBA 0.0 , SBA 0.9 & No tree-sized plants \\
\hline P3 & $3 \mathrm{yr}$ old, as above; TBA 0.0 , SBA 0.9 & No tree-sized plants \\
\hline
\end{tabular}

Species code: $\mathrm{As}=$ Acer saccharum, $\mathrm{Ar}=$ Acer rubrum, $\mathrm{Ba}=$ Betula alleghaniensis, $\mathrm{Bc}=$ Betula cordifolia, $\mathrm{Bp}=$ Betula papyrifera, $\mathrm{Fg}=$ Fagus grandifolia, $\mathrm{Pm}=$ Picea mariana, $\mathrm{Pg}=$ Picea glauca, $\mathrm{Pr}=$ Picea rubens .

and basal area $\left(\mathrm{m}^{2} / \mathrm{ha}\right)$ of trees, snags, and shrubs (only summary data are reported here; the details are in Fleming and Freedman 1998).

\section{Data Analysis}

The ground vegetation data for the plantations were analyzed to determine phytosociological changes during the 21-year sere. For some analyses, the species of ground vegetation were divided into nine functional guilds: feather mosses, other bryophytes, lichens, pteridophytes, gymnosperms, monocots, dicot herbs, dicot shrubs, and Rubus species. Changes associated with ecological conversion were examined by comparing plantations to reference forest. Species richness was calculated as the number of species encountered at each site. Species density was the average number of species per $\mathrm{m}^{2}$ quadrat. Species diversity was calculated as the Shannon-Weaver index (Cox 1996): $\mathrm{H}^{\prime}=-\Sigma\left(\mathrm{p}_{\mathrm{i}} \bullet \ln \mathrm{p}_{\mathrm{i}}\right)$, with $\mathrm{p}_{\mathrm{i}}$ of each species estimated using relative cover.

Multivariate analyses were used to explore relationships among stands. The data inputs were matrices of understorey species cover by site (Kovach 1995). To avoid undue influence of rare species, only the 79 species having an average cover $\geq 1 \%$ in at least one stand were used in the analyses. The analyses were performed using the MultiVariate Statistical Package (MVSP). A hierarchical cluster analysis was used to identify groupings of stands (or "communities"), using a procedure based on reciprocal averaging and divisions based on site attributes, with indicator species identified for the divisions in the classification (Gauch 1982; Kovach 1995). An ordination was performed by detrended correspondence analysis (DCA), which also calculates eigenvalues by a reciprocal averaging procedure; the detrending of the second and higher axes prevents a quadratic dependency, eliminating the potential for an arching effect (Gauch 1982). Compression of the axes is avoided by rescaling, so distances in the ordination space have consistent meaning in terms of compositional differences of samples.

\section{Results and Discussion}

Species Richness, Density, and Diversity

Species richness was greatest during the initial stages of the plantation sere, with a maximum of 170 species occurring in a six-year-old plantation (Table 2). Species richness then decreased to lower values in the oldest plantations, ranging from 98-112 species in stands 
TABLE 2. Ground vegetation species richness, density, and diversity in plantations and reference stands. The age of the reference stands is approximately 70 years.

\begin{tabular}{lcccc}
\hline \hline Stand & $\begin{array}{c}\text { Age } \\
\text { (years) }\end{array}$ & $\begin{array}{c}\text { Species Richness } \\
\text { (total species/site) }\end{array}$ & $\begin{array}{c}\text { Species Density } \\
\text { (species/m²) }\end{array}$ & $\begin{array}{c}\text { Species Diversity } \\
\text { (Shannon-Weaver) }\end{array}$ \\
\hline P3 & 3 & 135 & 11.4 & 2.99 \\
P4 & 4 & 120 & 13.4 & 3.17 \\
P5a & 5 & 146 & 16.2 & 3.53 \\
P5b & 5 & 77 & 16.3 & 3.71 \\
P6a & 6 & 170 & 17.6 & 3.34 \\
P6b & 6 & 128 & 18.8 & 3.46 \\
P7 & 7 & 141 & 20.9 & 3.18 \\
P8 & 8 & 124 & 18.1 & 2.40 \\
P13 & 13 & 98 & 18.7 & 2.85 \\
P15 & 15 & 112 & 15.1 & 2.39 \\
P18 & 18 & 80 & 11.5 & 2.27 \\
P21 & 21 & 98 & 11.9 & 2.97 \\
R1 & 70 & 92 & 13.1 & 3.33 \\
R2 & 70 & 141 & 17.4 & 2.62 \\
R3 & 70 & 98 & 10.8 & 2.80 \\
R4 & 70 & 92 & 14.5 & 2.35 \\
R5 & 70 & 102 & 14.6 & 2.94 \\
R6 & 70 & 100 & 14.4 & 2.46 \\
R7 & 70 & 74 & 11.1 & 3.00 \\
R8 & 70 & 93 & 11.3 & \\
\hline \hline
\end{tabular}

13-21 years old. Values similar to the oldest plantations occurred in mature reference stands (average of 99 species; the range was generally 74 to 102 species, with reference site two (R2) anomalous with 141 species).

Shannon-Weaver diversity ranged from 2.71 to 3.52 in plantations aged 3 to 8 years old (Table 2). Species diversity generally decreased through the plantation chronosequence, with the lowest value observed in the oldest stand, while reference stands ranged from 2.35 to 3.33 .

The higher species richness and diversity in young plantations is due to their relatively open conditions and the spatial heterogeneity of environmental factors and vegetation (Shafi and Yarranton 1973; Crowell and Freedman 1994). Other studies have reported relatively high richness and diversity of ground vegetation during the initial stages of succession after timber harvesting, followed by a large decline as more shaded conditions develop (Shafi and Yarranton 1973; Bormann and Likens 1979; Hibbs 1983; Schoonmaker and McKee 1988; Burton 1989; Reiners 1992; Crowell and Freedman 1994; Gilliam et al. 1995; Qi and Scarratt 1998; Roberts and Methven 1998). It has been suggested that the highest diversity of trees occurs in intermediate regenerative conditions, as this transitional period contains both early- and later-successional species (Loucks 1970; Auclair and Goff 1971; Pickett 1976; Connell 1978). In the understorey, however, competitive exclusion of intolerant species occurs earlier in succession because of the rapid development of a shading overstorey.

Species density was lowest in the youngest plantation surveyed (three years old), where it was $11.4 \mathrm{spp} . / \mathrm{m}^{2}$
(Table 2). It increased to $20.9 \mathrm{spp} . / \mathrm{m}^{2}$ in a seven-year plantation and then decreased and leveled off at 11.5$11.9 \mathrm{spp} . / \mathrm{m}^{2}$ in older stands. Species density in reference sites generally ranged from 10.8 to $14.6 \mathrm{spp} . / \mathrm{m}^{2}$ (average $13.4 \mathrm{spp} / \mathrm{m}^{2}$ ), with site R2 again anomalous with $17.4 \mathrm{spp} . / \mathrm{m}^{2}$. The lowest species density among reference stands was in a tolerant hardwood stand dominated by a closed canopy of Sugar Maple. Although species density is an infrequent variable in ecological studies, it was also reported by Reiners (1992) to increase during the initial years of natural regeneration after forest harvesting, peaking in a five-year-old stand.

\section{Changes in Cover}

The total cover of ground vegetation initially increased rapidly with plantation age. However, the highest values occurred in plantations aged 13 years $(130 \%)$ and 21 years $(140 \%)$, while the 18-year-old stand had a relatively low cover $(43 \%)$. The total cover in reference stands (average 68\%; range 40-98\%) was lower than in most plantations. Studies of natural regeneration after the clear-cutting of temperate hardwood or mixedwood forest have shown that an approximately complete foliar canopy of herbaceous and shrubsized plants can re-establish within only 4-6 years of disturbance, casting substantial shade over the forest floor (Bormann and Likens 1979; Burton 1989; Crowell and Freedman 1994). As the over-topping canopy of shrubs and trees further develops, there is a substantial decline in lower-growing plants of the ground vegetation.

The most abundant species in the ground vegetation of plantations aged 3 to 8 years old (listed in order of 
decreasing average cover) were: Cornus canadensis, Rubus strigosus, Picea mariana, Sphagnum girgensohnii, Polytrichum commune, Epilobium angustifolium, Solidago graminifolia, and Agrostis scabra. In plantations aged 13 to 21 years the most abundant species were: Picea mariana, Cornus canadensis, Pleurozium schreberi, Vaccinium myrtilloides, Polytrichum commune, Calamagrostis canadensis, Abies balsamea, and Betula cordifolia. Reference stands were dominated by: Dryopteris campyloptera, Dryopteris spinulosa, Cornus canadensis, Oxalis montana, Dennstaedtia punctilobula, Abies balsamea, Maianthemum canadense, and Viburnum alnifolium.

The most frequently encountered species in plantations aged 3 to 8 years old were: Rubus strigosus, Cornus canadensis, Maianthemum canadense, Agrostis scabra, Picea mariana, Cladonia spp., Pleurozium schreberi, and Solidago graminifolia. In plantations aged 13 to 21 years the most frequent taxa were: Cornus canadensis, Pleurozium schreberi, Picea mariana, Maianthemum canadense, Cladonia spp., Dicranum ontariense, and Polytrichum commune. The most frequent species in reference stands were: Maianthemum canadense, Oxalis montana, Dryopteris spinulosa, Cornus canadensis, Hypogymnia physodes, Dryopteris campyloptera, and Acer rubrum.

The overall successional pattern of species composition in plantations is one of increasing tolerance of the stressful conditions occurring beneath the developing overstorey (see Sparling 1967; Crowell and Freedman 1994; Freedman 1995). Species with the greatest prominence in younger plantations (up to 8 years old) varied in their ability to tolerate shading, as these stands included both ruderal invaders (such as Agrostis scabra, Epilobium angustifolium, Polytrichum commune, and Solidago graminifolia) and more tolerant ones that survived the disturbance event (e.g., Cornus canadensis, Maianthemum canadense, Picea mariana, and Pleurozium schreberi). Older plantations (13 to 21 years) contained fewer intolerant species and they were much less abundant. Although most species of the mature natural forest are shade tolerant, some intermediate and even intolerant plants occurred in open, patchy microhabitats associated with gap-phase disturbances (notably Rubus strigosus). Most of the reference stands had been affected by past infestations of Spruce Budworm, which caused selective mortality of mature balsam fir and spruce and created gaps in the canopy. Ruderal plants grew in these relatively open microhabitats; during microsuccession they are replaced by more competitive species.

Raspberry exemplifies elements of both the ruderal and competitor growth strategies (Grime 1979). After destruction of the overstorey by clear-cutting, Rubus species rapidly achieved prominence in the regenerating ground vegetation, mostly by the establishment of seedlings from a persistent seedbank (Grignon 1992). Rubus strigosus, the most abundant Rubus in our study, achieved its greatest cover within six years of the disturbance. The inability of Rubus spp. to tolerate shade soon resulted in a large reduction in its abundance (Whitney 1978; Grignon 1992; Archambault et al. 1998). However, Rubus species persisted in a small abundance within gap-disturbance microhabitats in older plantations and natural forest.

\section{Non-Native Species}

The great majority of vascular plants encountered within the plantation chronosequence are indigenous, as are all of the abundant species noted above. Although plantations supported some non-native plants (average of 4.9 species encountered per site; range 2$9 \mathrm{spp}$./site), their presence is ephemeral because these shade-intolerant ruderals became greatly diminished after an over-topping canopy developed (Table 3 ; there was a negative correlation ( $t$-test; $\mathrm{p}<0.005)$ between plantation age and relative cover of non-indigenous plants). Almost all non-native plants colonized the plantations through wind dispersal and exhibited a ruderal growth strategy. Reference stands had a much smaller frequency and cover of non-native species than plantations.

\section{Indicator Species of Reference Forest}

Although relatively few stands were surveyed in this study $(n=20)$, some species were found only in reference forest. These were: Acer pensylvanicum, Cephaloziella spp., Chiloscyphus spp., Fagus grandifolia, Lepidozia reptans, Nowellia curvifolia, Odontoschisma denudatum, and Viburnum alnifolium (see also Roberts and Methven 1998). These species may be considered indicators of the natural forest condition in our study region, and may potentially be at risk from extensive conversions of natural forest into plantations. However, none of the vascular plants encountered within this study is considered rare in New Brunswick (Hinds 1983).

The needs of these species may be accommodated by the use of "softer," less intensive management practices that favour their survival, such as shelterwood and selection harvesting (Atlegrim and Sjoberg 1996; Hannerz and Hanell 1997). However, more research on these less intensive systems must be undertaken to better understand how they affect understorey plants.

\section{Changes in Functional Guilds}

To aid in the interpretation of changes associated with succession and conversion in our extremely complex dataset, which consists of a matrix of 170 species by 20 sites, the ground vegetation was divided into the following functional guilds: feather mosses, other bryophytes, lichens, pteridophytes, gymnosperms, monocots, dicot herbs, dicot shrubs, and Rubus species (Table 4).

Feather mosses (mostly Pleurozium schreberi and Hylocomium splendens) occurred in low abundance during the initial 13 years of the plantation chronosequence, with average cover ranging from $<0.1 \%$ to 
TABLE 3. Non-native plants in plantations and natural forest. Numbers in brackets refer to the frequency of occurrence within stands of the indicated age-class.

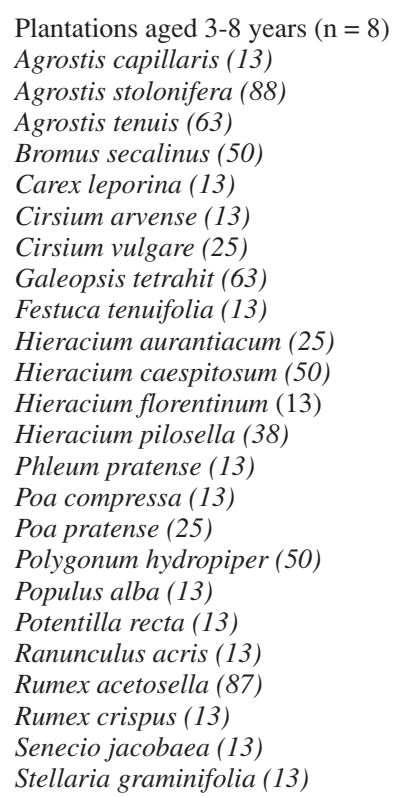

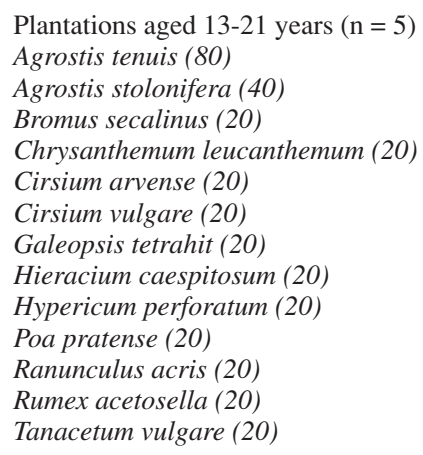


TABLE 4. Average cover $(\%)$ of functional guilds in a chronosequence of spruce plantations and in reference forest.

\begin{tabular}{lrrrrrrrrrrr}
\hline \hline Guild & P3 & P4 & P5a & P5b & P6a & P6b & P7 & P8 & P13 & P15 & P18 \\
\hline Feather mosses & 0.0 & 0.1 & 0.6 & 0.2 & 1.8 & 0.2 & 2.3 & 0.4 & 2.5 & 13.3 & 14.1 \\
Other bryophytes & 13.0 & 11.3 & 20.5 & 16.8 & 15.1 & 21.0 & 17.2 & 18.1 & 8.7 & 32.6 & 23.5 \\
Lichens & 0.4 & 0.8 & 2.2 & 2.3 & 1.4 & 0.0 & 1.1 & 1.3 & 2.7 & 3.1 & 1.9 \\
Pteridophytes & 0.3 & 3.1 & 0.5 & 1.0 & 4.9 & 0.7 & 4.1 & 2.7 & 14.3 & 0.0 & 0.7 \\
Gymnosperms & 1.5 & 8.7 & 6.3 & 7.4 & 9.1 & 0.7 & 9.9 & 19.6 & 39.0 & 31.3 & 0.0 \\
Monocots & 6.5 & 8.2 & 11.9 & 7.5 & 6.8 & 17.3 & 11.2 & 16.1 & 2.7 & 15.3 & 1.9 \\
Dicot herbs & 24.7 & 24.7 & 33.1 & 30.9 & 35.8 & 24.2 & 27.6 & 34.8 & 48.0 & 10.8 & 12.6 \\
Dicot shrubs & 4.1 & 2.2 & 3.8 & 2.6 & 10.5 & 2.2 & 5.3 & 8.6 & 9.8 & 12.0 & 2.5 \\
Rubus species & 6.4 & 9.8 & 8.3 & 11.8 & 21.0 & 15.1 & 13.8 & 8.9 & 4.9 & 0.5 & 0.3 \\
\hline TOTAL COVER & 56.7 & 68.7 & 86.6 & 80.3 & 104.5 & 81.3 & 90.1 & 110.0 & 130.0 & 105.5 & 43.3 \\
\hline Guild & $\mathrm{P} 21$ & $\mathrm{R} 1$ & $\mathrm{R} 2$ & $\mathrm{R} 3$ & $\mathrm{R} 4$ & $\mathrm{R} 5$ & $\mathrm{R} 6$ & $\mathrm{R} 7$ & $\mathrm{R} 8$ & $\mathrm{Ref}$ avg. \\
\hline Feather mosses & 49.4 & 0.1 & 8.5 & 0.0 & 0.3 & 1.1 & 0.1 & 2.7 & 2.9 & 2.0 \\
Other bryophytes & 67.5 & 2.5 & 17.6 & 2.9 & 5.9 & 9.2 & 3.0 & 9.1 & 9.1 & 7.4 \\
Lichens & 0.5 & 0.7 & 1.8 & 0.6 & 1.0 & 1.4 & 0.9 & 0.8 & 1.0 & 1.0 \\
Pteridophytes & 4.8 & 26.2 & 22.3 & 36.2 & 40.9 & 47.1 & 22.1 & 21.0 & 11.0 & 28.4 \\
Gymnosperms & 18.6 & 0.6 & 8.0 & 0.2 & 4.1 & 2.9 & 2.7 & 8.9 & 3.7 & 3.9 \\
Monocots & 0.4 & 7.7 & 0.1 & 3.3 & 3.3 & 1.8 & 1.6 & 2.6 & 0.3 & 2.6 \\
Dicot herbs & 18.0 & 9.0 & 24.4 & 8.1 & 16.8 & 26.7 & 8.4 & 12.9 & 11.2 & 14.7 \\
Dicot shrubs & 28.6 & 16.6 & 8.1 & 8.7 & 14.2 & 7.9 & 15.1 & 1.3 & 2.7 & 9.3 \\
Rubus species & 1.2 & 0.3 & 2.3 & 0.3 & 0.8 & 0.8 & 1.2 & 0.1 & 1.3 & 0.9 \\
\hline TOTAL COVER & 139.6 & 63.6 & 84.5 & 60.2 & 87.0 & 97.8 & 54.9 & 56.8 & 40.3 & 68.1 \\
\hline \hline
\end{tabular}

Red and White spruce (Anonymous 1965; Freedman 1995). In reference stands, gymnosperm cover ranged from 0.2 to $9 \%$ (average $4 \%$ ).

Monocots had a relatively high cover in younger plantations, with up to $17 \%$ in a 6-year-old stand. Some species (e.g., Carex trisperma) survived the initial disturbance event, while others (e.g., species of Agrostis) invaded the site afterward and were promi- nent in younger and intermediate seral stages. In reference stands monocots occurred at smaller but variable levels, averaging $2.6 \%$.

Dicot herbs were the most prominent element of the ground vegetation during the first years after plantation establishment, peaking in the 13-year-old plantation at $48 \%$ cover, with lower levels in reference stands (average 15\%). This mostly reflects species that seeded

TABLE 5. Cover values (\%) of the 17 most frequently encountered species by stand age. Where replicate stands (same age) were surveyed, the average is presented.

\begin{tabular}{|c|c|c|c|c|c|c|c|c|c|c|c|}
\hline Stand Age: & 3 & 4 & 5 & 6 & 7 & 8 & 13 & 15 & 18 & 21 & Reference \\
\hline Abies balsamea & 0.2 & 4.3 & 1.2 & 0.2 & 4.3 & 4.1 & 5.3 & 1.7 & 0.0 & 0.4 & 2.3 \\
\hline Acer rubrum & 0.5 & 0.0 & 0.9 & 0.7 & 0.2 & 1.8 & 2.8 & 0.0 & 0.3 & 0.0 & 1.2 \\
\hline Agrostis scabra & 1.2 & 2.3 & 3.4 & 3.1 & 2.1 & 0.2 & 0.1 & 0.0 & 0.0 & 0.0 & 0.0 \\
\hline Cornus canadensis & 0.0 & 13.0 & 34.0 & 11.0 & 8.6 & 23.0 & 42.0 & 7.0 & 12.0 & 14.0 & 8.0 \\
\hline Dennstaedtia punctilobula & 0.1 & 0.1 & 0.0 & 1.3 & 0.1 & 1.3 & 5.3 & 0.0 & 0.0 & 0.0 & 2.3 \\
\hline Dryopteris campyloptera & 0.0 & 0.0 & 0.0 & 0.2 & 0.0 & 0.0 & 3.2 & 0.0 & 0.0 & 0.0 & 14.0 \\
\hline Dryopteris spinulosa & 0.2 & 0.4 & 0.5 & 0.3 & 1.0 & 0.2 & 3.9 & 0.0 & 0.5 & 0.0 & 8.4 \\
\hline Maianthemum canadense & 0.8 & 1.0 & 1.2 & 0.3 & 1.1 & 0.5 & 1.3 & 2.6 & 0.2 & 0.2 & 1.9 \\
\hline Oxalis montana & 0.0 & 0.0 & 0.0 & 0.0 & 0.0 & 0.0 & 0.0 & 0.0 & 0.0 & 0.0 & 2.7 \\
\hline Picea mariana & 0.0 & 4.3 & 5.6 & 4.6 & 5.5 & 15.0 & 33.0 & 23.0 & 0.0 & 18.0 & 0.0 \\
\hline Pleurozium schreberi & 0.0 & 0.1 & 0.2 & 1.0 & 2.3 & 0.4 & 2.5 & 13.0 & 14.0 & 45.0 & 1.6 \\
\hline Polytrichum commune & 7.0 & 2.1 & 2.8 & 3.1 & 5.0 & 8.6 & 3.5 & 1.1 & 0.0 & 12.0 & 0.2 \\
\hline Polytrichum formosum & 0.0 & 3.5 & 3.3 & 3.9 & 4.7 & 0.6 & 0.1 & 2.1 & 1.0 & 1.8 & 0.1 \\
\hline Rubus striogosus & 6.0 & 7.1 & 5.7 & 17.0 & 12.0 & 8.3 & 4.9 & 0.4 & 0.0 & 0.7 & 0.5 \\
\hline Solidago graminifolia & 0.1 & 4.9 & 2.1 & 3.2 & 3.3 & 1.4 & 0.1 & 0.0 & 0.0 & 0.0 & 0.0 \\
\hline Solidago rugosa & 1.5 & 0.1 & 0.6 & 2.3 & 2.3 & 1.5 & 0.7 & 2.3 & 0.1 & 0.0 & 0.3 \\
\hline Sphagnum girgensohnii & 2.3 & 3.8 & 7.8 & 4.5 & 2.0 & 3.2 & 0.1 & 3.5 & 0.7 & 0.0 & 1.4 \\
\hline
\end{tabular}


into the disturbed sites, including asters (Aster spp., especially A. umbellatus), goldenrods (Solidago spp., especially $S$. rugosa), and fireweed (Epilobium angustifolium). These forbs declined rapidly after an overtopping canopy developed (Freedman 1995).

Dicot shrubs increased in cover with plantation age, with a maximum of $29 \%$ in the 21 -year plantation, while reference stands ranged from 8 to $27 \%$ (average $15 \%$ ). The average cover of Rubus species (mostly $R$. strigosus) was highest (21\%) in a 6-year plantation, followed by a decline in older plantations. Rubus cover averaged $0.9 \%$ in reference sites. The destruction of the overstorey by clear-cutting stimulated a long-lived seedbank of certain species to germinate (particularly Red Elderberry, Sambucus racemosa; Pin-Cherry, Prunus pensylvanica; and Raspberry, Rubus spp., especially $R$. strigosus). In addition, some woody plants that survived the disturbance then regenerated vigorously by stump-sprouting (e.g., Red Maple, Acer rubrum, and Beech, Fagus grandifolia) (Anonymous 1965; Lees 1981; Beatty 1991; Crowell and Freedman 1994; Qi and Scarratt 1998).

\section{Multivariate Analyses}

The cluster analysis identified five natural groupings or "communities" among the 20 stands surveyed (Figure 1). Clusters were largely based on attributes related to stand age and on plantation versus natural forest. Variation not accounted for by the cluster analysis may be due to the influence of site factors we did not study, such as spruce-budworm dynamics, topography, elevation, microclimate, and soil (Roberts and Methven 1998). The five community types identified are:

- Group 1: Older plantations, aged 13, 15, and 21 years since establishment

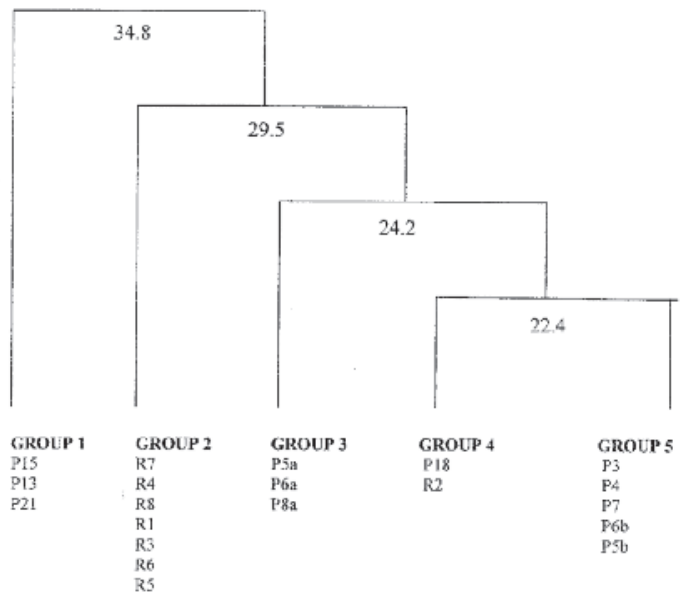

FIGURE 1. Graphical representation of cluster analysis results for 8 reference stands and 12 plantations. The analysis was based on the average cover of species of lichens, bryophytes, and vascular plants in the ground vegetation. Numbers represent eigenvalues.
- Group 2: Reference stands (except for R2; see below)

- Group 3: Middle-aged plantations (5, 6, and 8 years old)

- Group 4: An 18-year-old plantation and a reference stand (R2)

- Group 5: The youngest plantations (3, 4, 5, 6, and 7 years-old)

Axes 1 and 2 of the detrended correspondence analysis accounted for $19.7 \%$ and $12.6 \%$, respectively, of the observed variance, while axes 3 and 4 accounted for only $5.2 \%$ and $2.3 \%$, respectively, and provided no obvious ecological interpretation. Axes 1 and 2 separated reference stands (situated on the right-hand side of the plot) from plantations (to the left; Figure 2). The plantations are generally ordered according to age. Stands tended to ordinate with their "community" according to the cluster analysis, suggesting a robust analysis in terms of successional and conversion factors being the primary influences on differences in ground vegetation among stands in our study.

\section{Conclusions}

The clear-cutting of natural, mixed-species forest followed by plantation establishment initiates a vigorous regeneration of the ground vegetation and a reorganization of its communities. Species inhabit temporally varying habitats in the plantation chronosequence, depending on their abilities to survive the disturbance, colonize the site, take advantage of a temporary flush of resources, and/or tolerate intensifying ground-level stress as the overstorey develops. However, extensive plantation development results in increasingly fewer habitats suitable for species that grow preferentially or exclusively in older, natural forest. This may limit the ability of those species to maintain viable populations within an intensively managed landscape. More research is needed to identify species that are vulnerable to extensive forestry-related habitat conversions, and to provide information necessary to accommodating their needs by changing the management system and by designating a comprehensive system of protected areas. These vulnerable species are also potentially useful in monitoring programs as indicators of ecological integrity and of the sustainability of forestry operations (Woodley et al. 1993; Biodiversity Science Assessment Team 1994; Freedman et al. 1997).

\section{Acknowledgments}

This study was supported by research grants to B. Freedman from the Natural Sciences and Engineering Research Council of Canada and the Greater Fundy Ecosystem Research Group, by a research contract from the Fundy Model Forest, and by a Dalhousie University Graduate Fellowship to C. Veinotte. Additional support was provided by Parks Canada and the staff of Fundy National Park. J. D. Irving Forest Products Limited allowed access to their plantations and provided information regarding management prac- 


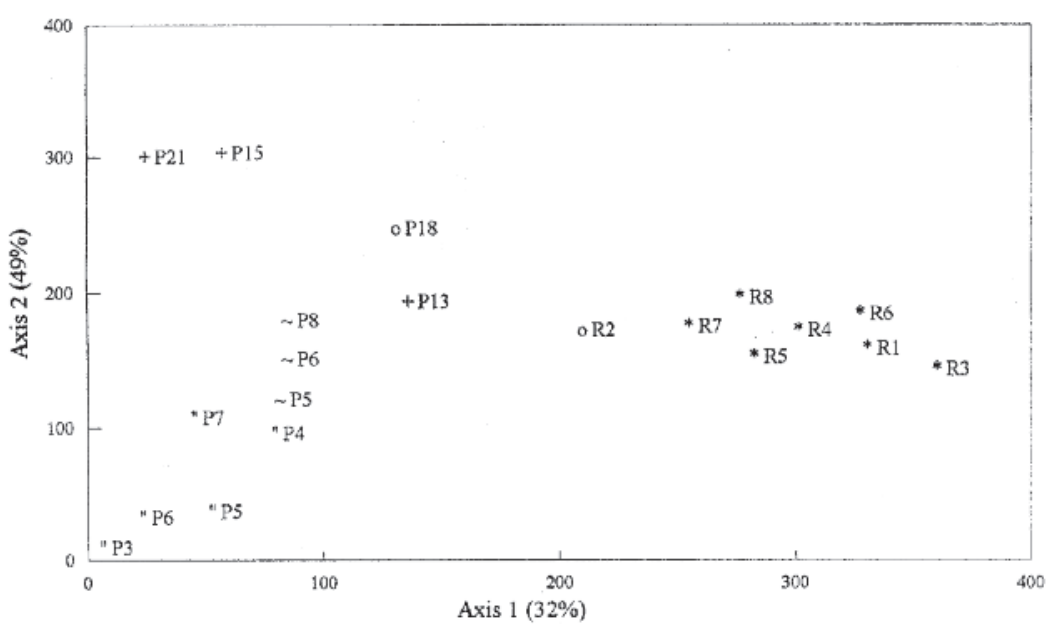

FIGURE 2. Stand scores of axes 1 and 2 of the detrended correspondence analysis ( 8 reference stands and 12 plantations). "P" and "R" denote plantation and reference stands, respectively. Symbols correspond to the group or "community" to which stands were assigned by the cluster analysis, where: + is Group 1, * is Group 2, is Group 3, o is Group 4, and " is Group 5.

tices. We are also grateful to Tracy Fleming, Jonathan Freedman, Greg Johnson, and Kathleen O'Sullivan for their assistance with fieldwork. Nick Hill of Mount St. Vincent University provided comments on an early draft.

\section{Literature Cited}

Anonymous. 1965. Silvics of Forest Trees of the United States. Agricultural Handbook (271), USDA Forest Service, Washington, D.C.

Anonymous. 1986. Ecological effects of clear-cutting. Pages 345-357 in Ecological Knowledge and Environmental Problem-Solving. Concepts and Case Studies. Committee on the Applications of Ecological Theory to Environmental Problems. National Academy Press, New York.

Auclair, A. N., and F. G. Goff. 1971. Diversity relations in the upland forests of the western Great Lakes area. American Naturalist 105: 499-528.

Archambault, L., J. Morissette, and M. Bernier-Cardou. 1998. Forest succession over a 20 -year period following clearcutting in balsam fir-yellow birch ecosystems of eastern Quebec, Canada. Forest Ecology and Management 102: 61-74.

Atlegrim, O. and K. Sjoberg. 1996. Response of bilberry (Vaccinium myrtillus) to clear-cutting and single-tree selection harvests in uneven-aged boreal Picea abies forests. Forest Ecology and Management 86: 39-50.

Beatty, S. W. 1991. Colonization dynamics in a mosaic landscape: The buried seed pool. Journal of Biogeography 18: 553-563.

Biodiversity Science Assessment Team. 1994. Biodiversity in Canada: A science assessment for Environment Canada. Environment Canada, Ottawa, Ontario.

Bormann, F. H., and G. E. Likens. 1979. Pattern and Process in a Forested Ecosystem. Springer-Verlag, New York.

Brodo, I. M., S. D. Sharnoff, and S. Sharnoff. 2001. Lichens of North America. Yale University Press, New Haven, Connecticut.
Burton, S. M. 1989. Vegetation changes in a post-clear-cutting succession of mixedwood and softwood forests in Nova Scotia. M.Sc. thesis, Dalhousie University, Halifax, Nova Scotia.

Burzynski, M. P. 1985. A guide to Fundy National Park. Douglas \& McIntyre, Vancouver, British Columbia.

Burzynski, M. P., S. J. Woodley, and A. Marceau. 1986. The vascular flora of Fundy National Park, New Brunswick. New Brunswick Museum, Publications in Natural Science (4), Saint John, New Brunswick.

Canada Soil Survey Committee. 1978. The Canadian System of Soil Classification. Agriculture Canada, Canadian Soil Survey Committee, Publication 1646, Ottawa, Ontario.

Cody, W. J., I. V. Hall, and C. W. Crompton. 1977. The biology of Canadian weeds. 26. Dennstaedtia punctilobula (Michx.) Moore. Canadian Journal of Plant Science 57: 1159-1168.

Connell, J. H. 1978. Diversity in tropical rainforests and coral reefs. Science 199: 1302-1310.

Cox, G.W. 1996. Laboratory Manual of General Ecology, $7^{\text {th }}$ Edition. Wm. C. Brown Publishers, Chicago.

Crowell, M., and B. Freedman. 1994. Vegetation development in a hardwood-forest chronosequence in Nova Scotia. Canadian Journal of Forestry Research 24: 260-271.

Crum, H. 1976. Mosses of the Great Lakes Forest. University of Michigan, Ann Arbor.

Ecological Stratification Working Group. 1995. A National Ecological Framework for Canada. Environment Canada, State of the Environment Directorate, Ecozone Analysis Branch, Hull, Quebec.

Fleming, T. L., and B. Freedman. 1998. Conversion of natural, mixed-species forests to conifer plantations: Implications for dead organic matter and carbon storage. Ecoscience 5: 214-221.

Foster, D. R. 1985. Vegetation development following fire in Picea mariana (black spruce)-Pleurozium forests of south-eastern Labrador, Canada. Journal of Ecology 73: 517-534. 
Freedman, B. 1995. Environmental Ecology, $2^{\text {nd }}$ edition. Academic Press, San Diego, California.

Freedman, B., S. Woodley, and J. Loo. 1994. Forestry practices and biodiversity, with particular reference to the Maritime provinces of eastern Canada. Environmental Reviews 2: 33-77.

Freedman, B., S. Woodley, and G. Forbes. 1997. The Greater Fundy Ecosystem: Planning for an ecologically sustainable landscape. Pages 114-118 in Protected Areas in Our Modern World. Proceedings of a Workshop Held as Part of the IUCN World Conservation Congress, Montreal, Que., October, 1996.

Gilliam, F. S., N. L. Turrill, and M. B. Adams. 1995. Herbaceous-layer and overstorey species in clear-cut and mature central Appalachian hardwood forests. Ecological Applications 5: 947-955.

Grime, J. P. 1979. Plant Strategies and Vegetation Processes. John Wiley \& Sons, New York.

Gauch, H. G. 1982. Multivariate Analysis in Community Ecology. Cambridge University Press, Cambridge, UK.

Grignon, T. G. 1992. The Dynamics of Rubus strigosus (Michx.) in Post-Clearcut Mixedwood and Softwood Forests of Nova Scotia. M.Sc. thesis, Dalhousie University, Halifax, Nova Scotia.

Hale, M. 1974. The Biology of Lichens. Wm. C. Brown Publishers, Iowa.

Hannerz, M., and B. Hanell. 1997. Effects on the flora in Norway spruce forests following clearcutting and shelterwood cutting. Forest Ecology and Management 90: 29-49.

Hibbs, D. E. 1983. Forty years of forest succession in central New England. Ecology 64: 1394-1401.

Hinds, H. 1983. The Rare Vascular Plants of New Brunswick. Syllogeus 50, National Museums of Canada, Ottawa, Ontario.

Hinds, H. 2000. Flora of New Brunswick, $2^{\text {nd }}$ edition. University of New Brunswick, Fredericton.

Hunter, M. L. 1999. Maintaining Biodiversity in Forest Ecosystems. Cambridge University Press, Cambridge, UK.

Kimmins, J. P. 2003. Forest Ecology: A Foundation for Sustainable Management, $3^{\text {rd }}$ edition. Prentice Hall College Division, Menlo Park, California.

Kohm, K., and J. F. Franklin. Editors. 1997. Creating a Forestry for the $21^{\text {st }}$ Century: The Science of Ecosystem Management. Island Press, Washington, D.C.

Kovach, W. L. 1995. MultiVariate Statistical Package (MVSP) Plus, Version 2.2d. Kovach Computing Services, Wales, UK.

Lees, J. C. 1981. Three generations of red maple stump sprouts. Canadian Forestry Service, Information Report M-X-119. Fredericton, New Brunswick.

Lindenmayer, D. B., and J. F. Franklin. 2002. Conserving Forest Biodiversity: A Comprehensive Multiscaled Approach. Island Press, Washington, D.C.

Loucks, O. L. 1962. A forest classification for the Maritime Provinces. Proceedings of the Nova Scotia Institute of Science 25: 85-167.
Loucks, O. L. 1970. Evolution of diversity, efficiency, and community stability. American Zoologist 10: 17-25.

Maliondo, S. M., M. K. Mahendrappa, and G. D. Van Raalte. 1990. Distribution of biomass and nutrients in some New Brunswick forest stands: Possible implications of whole-tree harvesting. Canadian Forestry Service, Information Report M-X-170E/F. Fredericton, New Brunswick.

Mallik, A. U., F. W. Bell, and Y. Gong. 1997. Regeneration behavior of competing plants after clear cutting: implications for vegetation management. Forest Ecology and Management 95: 1-10.

Pickett, S. T. A. 1976. Succession: An evolutionary interpretation. American Naturalist 110: 107-119.

Qi, M., and J. B. Scarratt. 1998. Effect of harvesting method on seed bank dynamics in a boreal mixedwood forest in northwestern Ontario. Canadian Journal of Botany 76: 872-883.

Reiners, W. A. 1992. Twenty years of ecosystem reorganization following experimental deforestation and regrowth suppression. Ecological Monographs 62: 503-523.

Roberts, M. R., and I. R. Methven. 1998. Effects of forestry practices on species composition and taxonomic and structural diversity. Pages 83-85 in State of the Greater Fundy Ecosystem. Edited by S. Woodley, G. Forbes, and A. Skibicki. Greater Fundy Ecosystem Research Group, University of New Brunswick, Fredericton, New Brunswick.

Rowe, J. S. 1972. Forest Regions of Canada. Canadian Forestry Service, Ottawa, Ontario.

Schoonmaker, P., and A. McKee. 1988. Species composition and diversity during secondary succession of coniferous forests in the Western Cascade Mountains of Oregon. Forest Science 34: 960-979.

Shafi, M. I., and G. A. Yarranton. 1973. Diversity, floristic richness, and species evenness during a secondary (postfire) succession. Ecology 54: 897-902.

Smith, R. L. 1980. Ecology and Field Biology, $3^{\text {rd }}$ edition. Harper and Row Publishers, New York.

Sparling, J. H. 1967. Assimilation rates of some woodland herbs in Ontario. Botanical Gazette 128: 160-168.

Whitney, G. G. 1978. A Demographic Analysis of Rubus idaeus L. and Rubus pubescens Raf. The Reproductive Traits and Population Dynamics of Two Temporally Isolated Members of the Genus Rubus. Ph.D. dissertation, Yale University, Connecticut.

Woodley, S. J. Editor. 1985. Fundy National Park: Resource Description and Analysis. Parks Canada, Halifax, Nova Scotia.

Woodley, S., G. Forbes, and A. Skibicki. 1998. State of the Greater Fundy Ecosystem. Greater Fundy Ecosystem Research Group, University of New Brunswick, Fredericton, New Brunswick.

Woodley, S., J. Kay, and G. Francis. 1993. Ecological Integrity and the Management of Ecosystems. Heritage Resource Centre, University of Waterloo, Ontario.

Received 27 August 2001

Accepted 15 April 2004 